\title{
FLOOD OF
}

OCTOBER 8, 1977 IN ST. CROIX,

U.S. VIRGIN ISLANDS

$C A R I B B E A N$ S EA

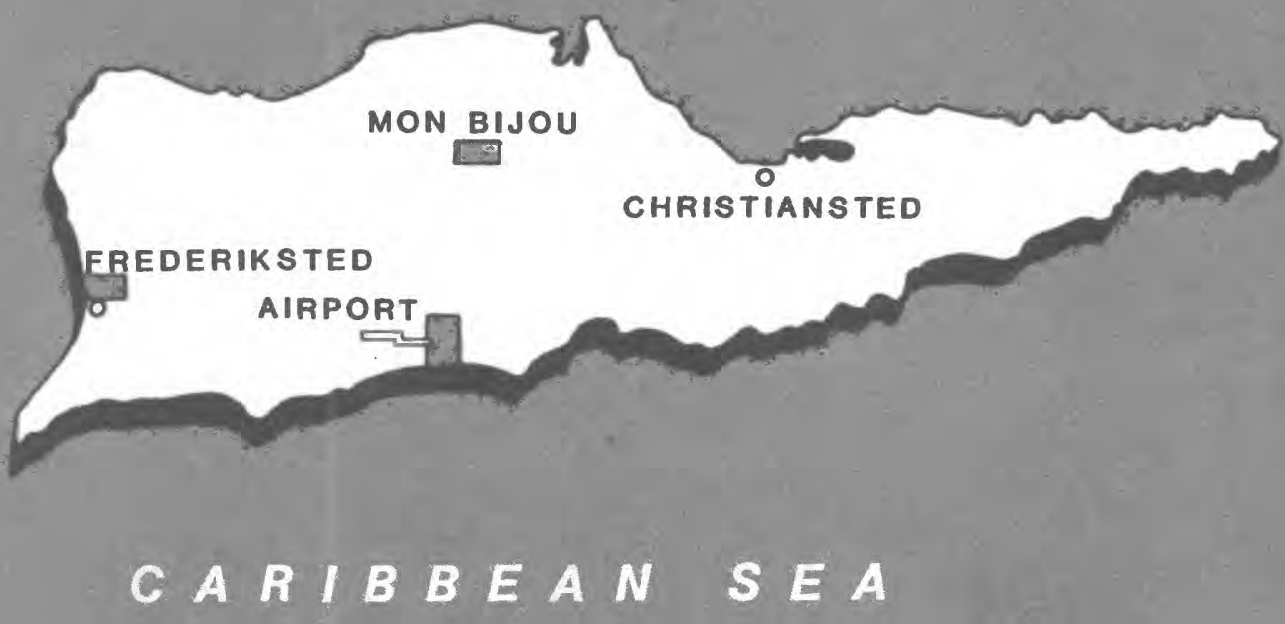

UNITED STATES GEOLOGICAL SURVEY WATER RESOURCES INVESTIGATIONS 82-262 OPEN-FILE REPORT

\section{PREPARED IN COOPERATION WITH THE}




\title{
FLOOD OF \\ OCTOBER 8, 1977 \\ IN ST. CROIX, \\ U.S. VIRGIN ISLANDS
}

\author{
BY \\ KARL G. JOHNSON, \\ RAMON A. CARRASQUILLO, AND RALPH GONZALEZ
}

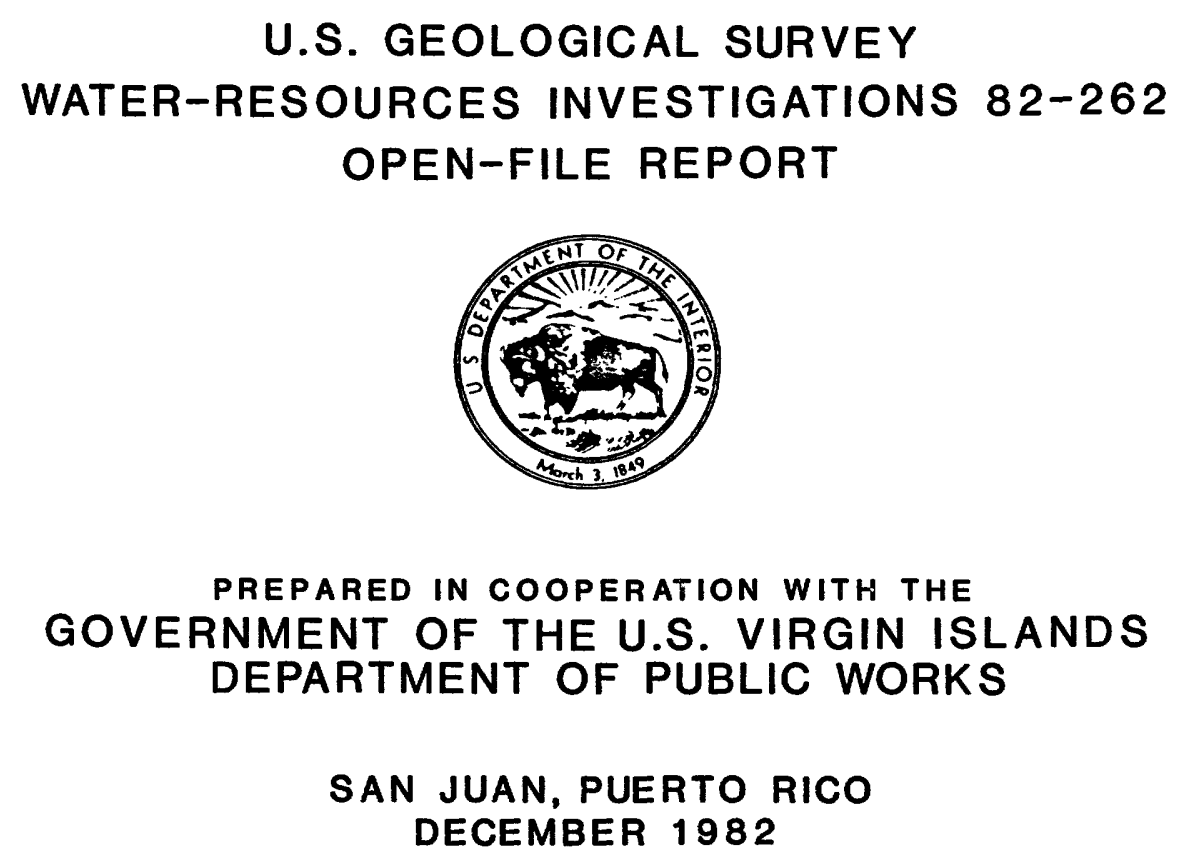




\title{
UNITED STATES DEPARTMENT OF THE INTERIOR
}

\author{
JAMES G. WATT, Secretary
}

GEOLOGICAL SURVEY

DALLAS L. PECK, Director

For additional information

write to:

District Chlef

U.S. Geologlcal Survey

GPO BOX 4424

San Juan, PR 00936
Coples of thls report can be purchased from:

Open-flle Services section U.S. Geologlcal Survey Box 25425, Federal Center Lakewood, Colorado 80225 


\section{CONTENTS}

Page

Abstract......................................... 1

1.0 Introduction............................... 2

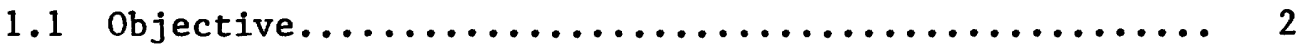

1.2 Study area........................... 4

2.0 Historical floods.......................... 6

3.0 The flood of October $8,1977 \ldots \ldots \ldots \ldots \ldots \ldots \ldots \ldots \ldots \ldots, 8$

3.1 Precipitation........................ 8

3.2 Flooded areas............................... 10

3.3 Flood profiles (Plates 1,2, and 3 in Pocket)....... 12

3.4 Depth of flooding............................. 14

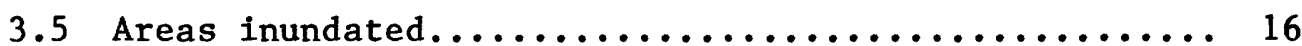

4.0 Elevation of bridges and culverts and reference marks..... 18

5.0 List of references......................... 20

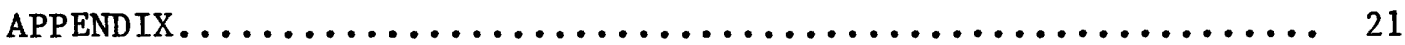

PLATE 1 Flood map of Frederiksted area............ (In Pocket)

PLATE 2 " " "Mon Bijou area.............. (In Pocket)

PLATE 3 " " " airport area ............... (In Pocket) 


\section{FACTORS FOR CONVERTING INCH-POUND UNITS TO INTERNATIONAL SYSTEM OF METRIC UNITS (SI)}

For the convenience of readers who may want to use International System of Unit (SI), the inch-pound units may be converted by using the following factors:

\begin{tabular}{|c|c|c|}
\hline Multiply the inch-pound units & By & To obtain the SI units \\
\hline inches (in) & 25.4 & millimeters (mm) \\
\hline feet $(f t)$ & 0.3048 & meters (m) \\
\hline feet per mile $(\mathrm{ft} / \mathrm{mi})$ & 0.1894 & $\begin{array}{l}\text { meters per kilometers } \\
\qquad(\mathrm{m} / \mathrm{km})\end{array}$ \\
\hline miles (mi) & 1.609 & kilometers (km) \\
\hline square miles $\left(\mathrm{mi}^{2}\right)$ & 2.590 & square kilometers $\left(\mathrm{km}^{2}\right)$ \\
\hline cubic feet per second $\left(\mathrm{ft}^{3} / \mathrm{s}\right)$ & 0.02832 & $\begin{array}{l}\text { cubic meters per second } \\
\qquad\left(\mathrm{m}^{3} / \mathrm{s}\right)\end{array}$ \\
\hline
\end{tabular}

\section{ACKNOWLEDGMENTS}

Manuscript Typing............ Carmen A. Garcia

Drafting and Art........................José Alicea

Report Review................. Donald G. Jordan 
FLOOD OF OCTOBER 8, 1977

IN ST. CROIX, U.S. VIRGIN ISLANDS

\author{
BY \\ KARL G. JOHNSON \\ RAMON A. CARRASQUILLO, AND RALPH GONZALEZ
}

\begin{abstract}
Severe flooding throughout St. Croix, United States Virgin Islands occurred on October 8, 1977. A tropical storm moving across the island produced as much as 16 inches of precipitation. The most affected areas were near Frederiksted, Mon Bijou, and the Airport. The peak discharge of River Gut near the Airport was about 11,400 cubic feet per second.
\end{abstract}

The water depth in some urban areas exceeded 4.0 feet. F1ood maps and flood profiles show the inundated areas near Frederiksted, Mon Bijou and the Airport. 


\subsection{INTRODUCTION \\ 1.1 OBJECTIVE}

\section{FLOOD OF OCTOBER 8, 1977 IN ST. CROIX DELINEATED}

\section{This report presents maps of \\ three areas in St. Croix, U.S. Virgin Istands, inundated during the October 8,1977 flood.}

St. Croix, in the U.S. Virgin Islands, is located in the pathway of tropical storms and hurricanes, in the western edge of the Lesser Antilles (fig. 1.1-1). Tropical disturbances also occur frequently, creating intense precipitation which occasionally may exceed 18 inches in a 48-hour period (Jordan, 1975).

A tropical storm moved across St. Croix during October 7-8, 1977. Severe flooding at several places in the Island occurred on October 8 , from the intense precipitation generated by the disturbance.

This report documents the magnitude of the floods and defines the inundated areas. The information in the report will be useful to planners and managers involved in flood-plain development. It will also provide a record for future studies seeking to define the frequency of these and other floods. The report was prepared in cooperation with the Government of the U.S. Virgin Islands, Department of Public Works. 


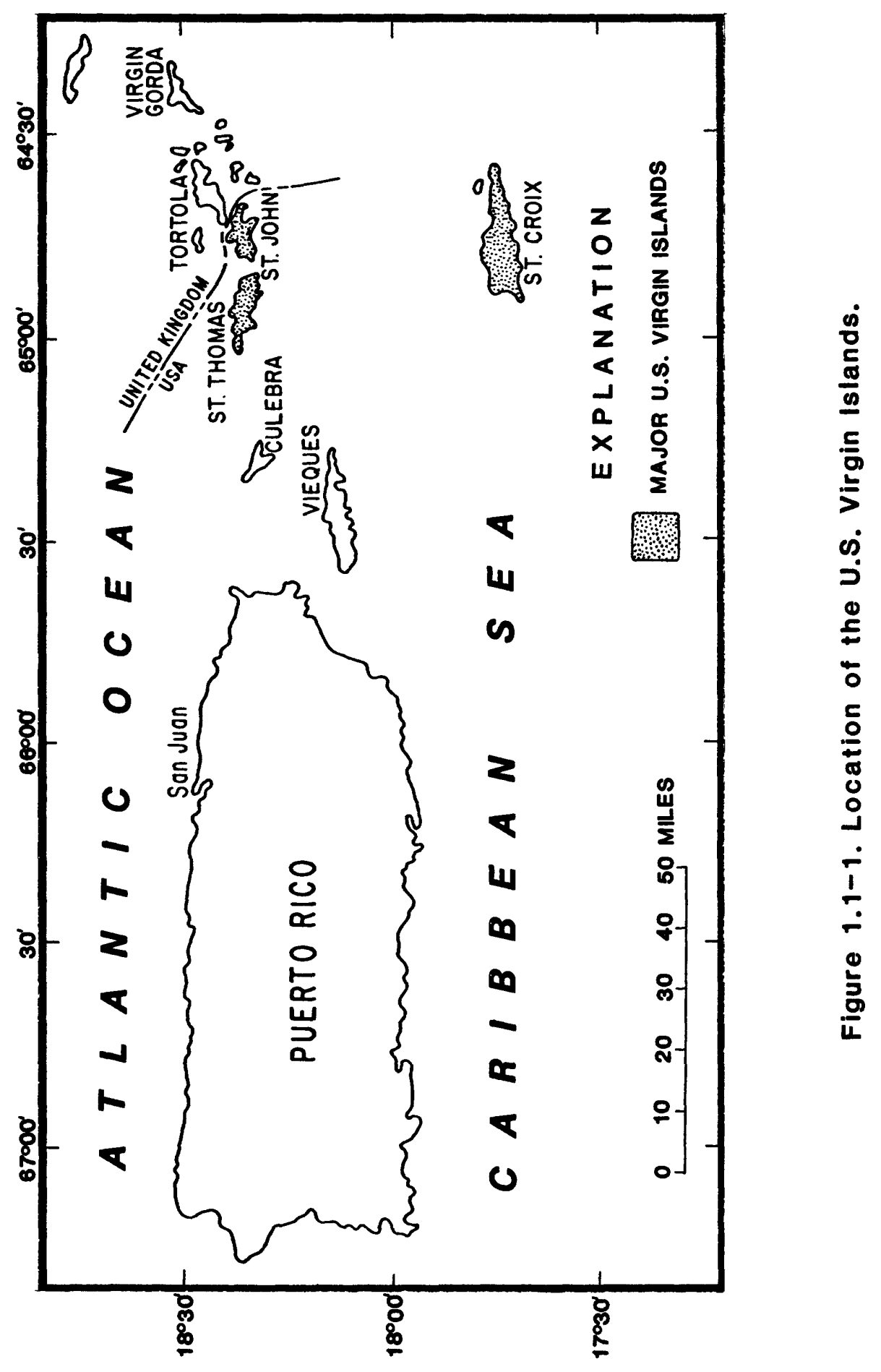




\subsection{INTRODUCTION (Continued) \\ 1.2 STUDY AREA}

\section{FLOODING DEFINED IN THREE AREAS IN ST. CROIX}

\section{The most severe flooding occurred in the Frederiksted, Mon Bijou, and Airport areas.}

St. Croix is the largest of the U.S. Virgin Islands, with an area of about $84 \mathrm{mi}^{2}$. It 1 ies about $50 \mathrm{mi}$ east of Puerto Rico, and about $40 \mathrm{mi}$ south of St. Thomas and St. John.

The northwestern part of St. Croix is a rugged area of mountains of volcanic origin (fig. 1.2-1). The crest of the mountains ranges from 600 to 1,100 feet abnre mean sea level. The south and soutbwest parts of the Island form a gently rolling alluvial plain underlain by limestone and marl. The eastern part of St. Croix is a penninsula of mountain and shallow valleys, with some peaks reaching $800 \mathrm{ft}$ above mean sea leve1.

Four major streams flow intermittently in St. Croix, all in the western half of the Island. River Gut, the largest, has a drainage area of about $11 \mathrm{mi}^{2}$.

The principal areas affected by the flood of October 8, 1977 were near the Frederiksted, (Jolly Hill Gut); and Mon Bijou, (Salt River); Airport (River Gut). 


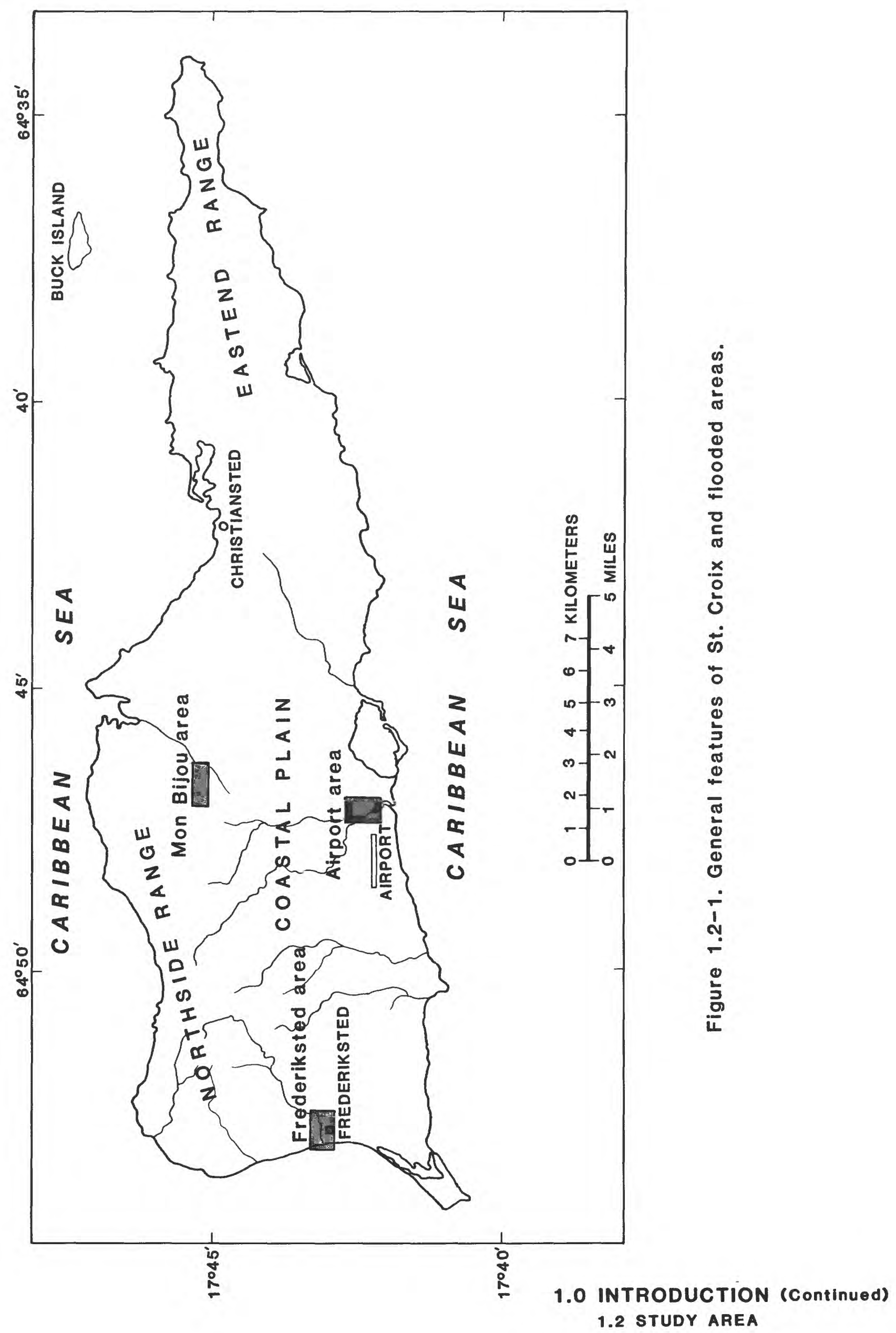




\subsection{HISTORICAL FLOODS}

\section{FREQUENT FLOODS HAVE OCCURRED DURING THIS DECADE}

\section{Severe flooding occurred in 1974 and 1977.}

The island of St. Croix has been affected by severe floods twice during the last ten years. The storm of November 11-13, 1974 inundated large areas at Campo Rico, Whim, Car1ton, Plessen, Christiansted, and Tide Village (fig. 2.0-1). In 1977, these areas as well as areas near Frederiksted, Mon Bijou, and the Airport were flooded.

The storms of 1974 and 1977 were of similar magnitude. The recurrence interval of the 1974 floods ranges from 3 to 25 years (Haire and Johnson, 1978). Sufficient information to estimate the recurrence interval of the 1977 floods is not available. 


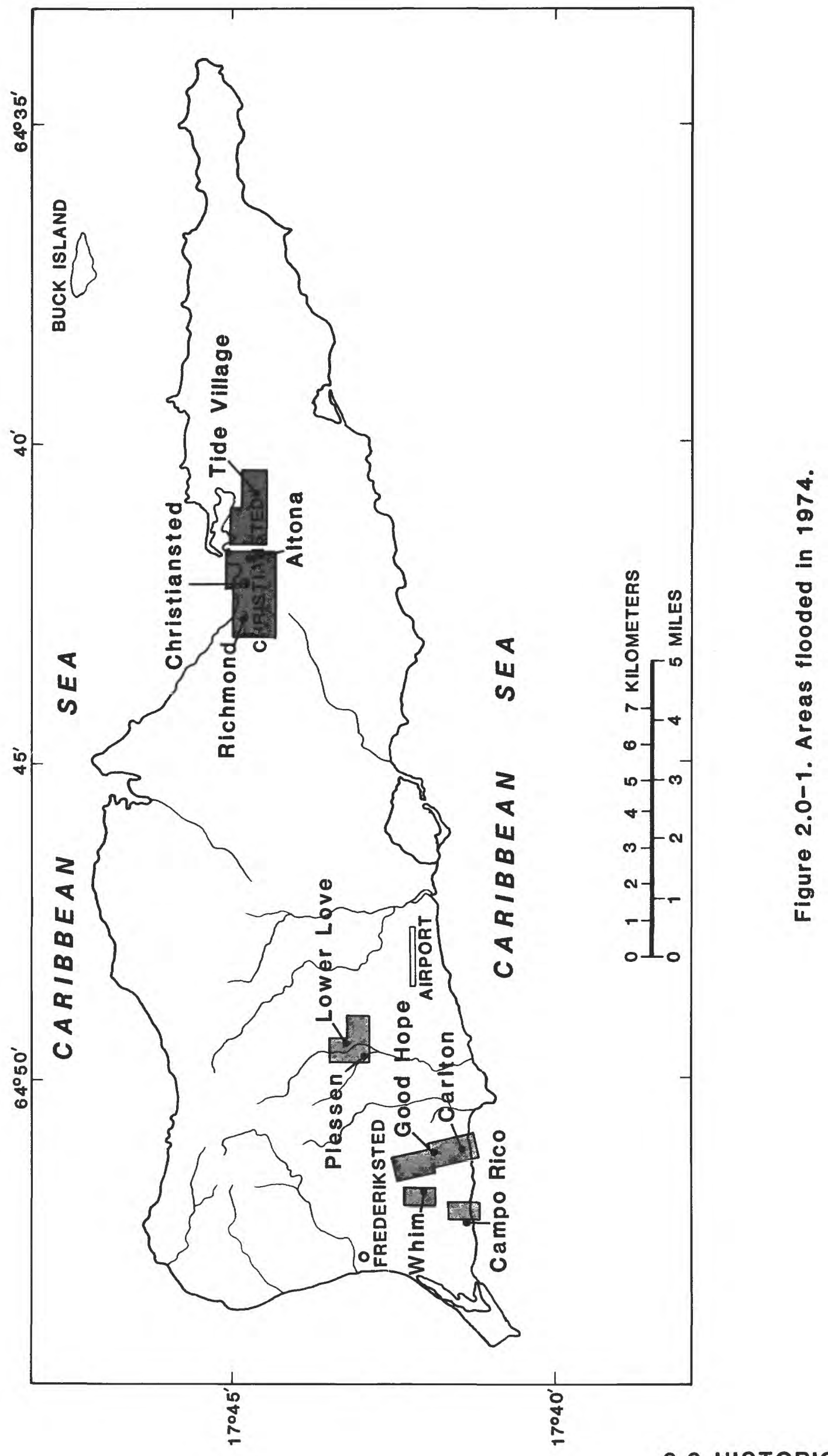

2.0 HISTORICAL FLOODS 


\subsection{THE FLOOD OF OCTOBER 8, 1977 3.1 PRECIPITATION}

\section{PRECIPITATION DURING THE OCTOBER 7-8 STORM RANGED FROM 8 TO 16 INCHES}

\section{In the area northeast of Frederiksted, cumulative precipitation averaged 16 inches.}

Annual precipitation on St. Croix averages about 40 inches, ranging from 30 inches in the east to 50 inches in the mountains of the northwest. Temperature averages about $79^{\circ} \mathrm{F}$, with prevailing winds from the east or northeast.

The tropical disturbance that produced the floods of 0ctober 8 , 1977, moved over St. Croix on October 7. Precipitation was intense and cumulative totals over the Island ranged from 8 to 16 inches (fig. 3.1-1 and table $3 \cdot 1-1)$. The largest amounts of rainfall during the storm (about 16 inches) were recorded in the headwater of Jo11y Hill Gut, northeast of Frederiksted. From 12 to 14 inches were recorded at sites in the basins of River Gut and the Salt River.

The drainage basins in St. Croix are generally steep, and river stages peak within a short time after precipitation. Although a significant amount of precipitation may be required before runoff exceeds 20 percent of precipitation (Jordan, 1975), antecedent wet-soil conditions can contribute to sizable runoff and flooding. 

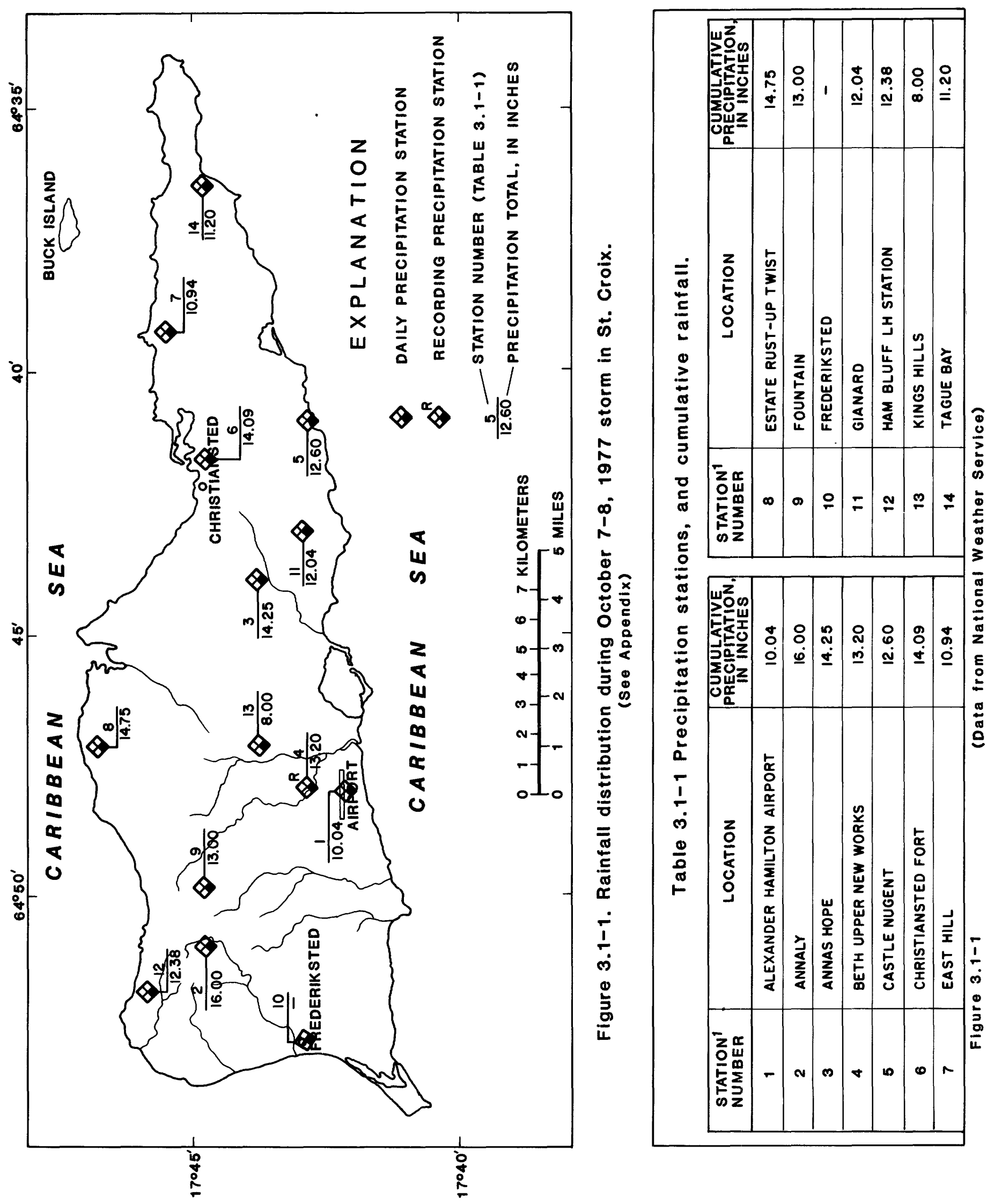

3.0 THE FLOOD OF OCTOBER 8, 1977

3.1 PRECIPITATION 


\subsection{THE FLOOD OF OCTOBER 8, 1977 (Continued) \\ 3.2 PEAK DISCHARGE}

\section{FLOODING WAS MOST SEVERE IN THE FREDERIKSTED, MON BIJOU, AND AIRPORT AREAS}

\section{Peak discharge at River Gut near the airport was about $11,400 \mathrm{ft}^{3} / \mathrm{s}$, while at Mon Bljou it was about 6,200 $\mathrm{ft}^{3} / \mathrm{s}$.}

The flooded areas described in this report include Frederiksted, Mon Bijou, and the vicinity of the Airport (fig. 3.2-1 and plates 1, 2, and 3). The magnitude of the flooding in the other affected areas was similar to or less than that of the floods of November 11-13, 1974, as reported by Haire and Johnson (1974). Therefore, flooded areas defined by Haire and Johnson are not delineated in this report.

Peak discharges at two of the flooded sites were estimated using indirect-measurement techniques. At River Gut near the Airport, the estimated peak discharge was about $11,400 \mathrm{ft}^{3} / \mathrm{s}$. At Mon Bijou, the estimated peak discharge was about $6,200 \mathrm{ft}^{3} / \mathrm{s}$.

Peak discharges can be compared on the basis of drainage area to maximum discharges at other basins throughout the world (Lindsey and others, 1949). The discharge data for Mon Bijou and River Gut, as well as Myers comparison curves, are plotted in figure 3.2-2. The comparison shows that the Airport flood was less than 50-percent Myers rating. The Mon Bijou flood on the other hand, was greater than the 50-percent Myers rating and approaches the 80 -percent yield curve, indicating a flood of greater relative magnitude. As a comparison, 9 sites of 24 affected by the floods of 1960 in eastern Puerto Rico exceeded the 80-percent Myers rating (Barnes and Bogart, 1961). These floods were the greatest known in Puerto Rico. 


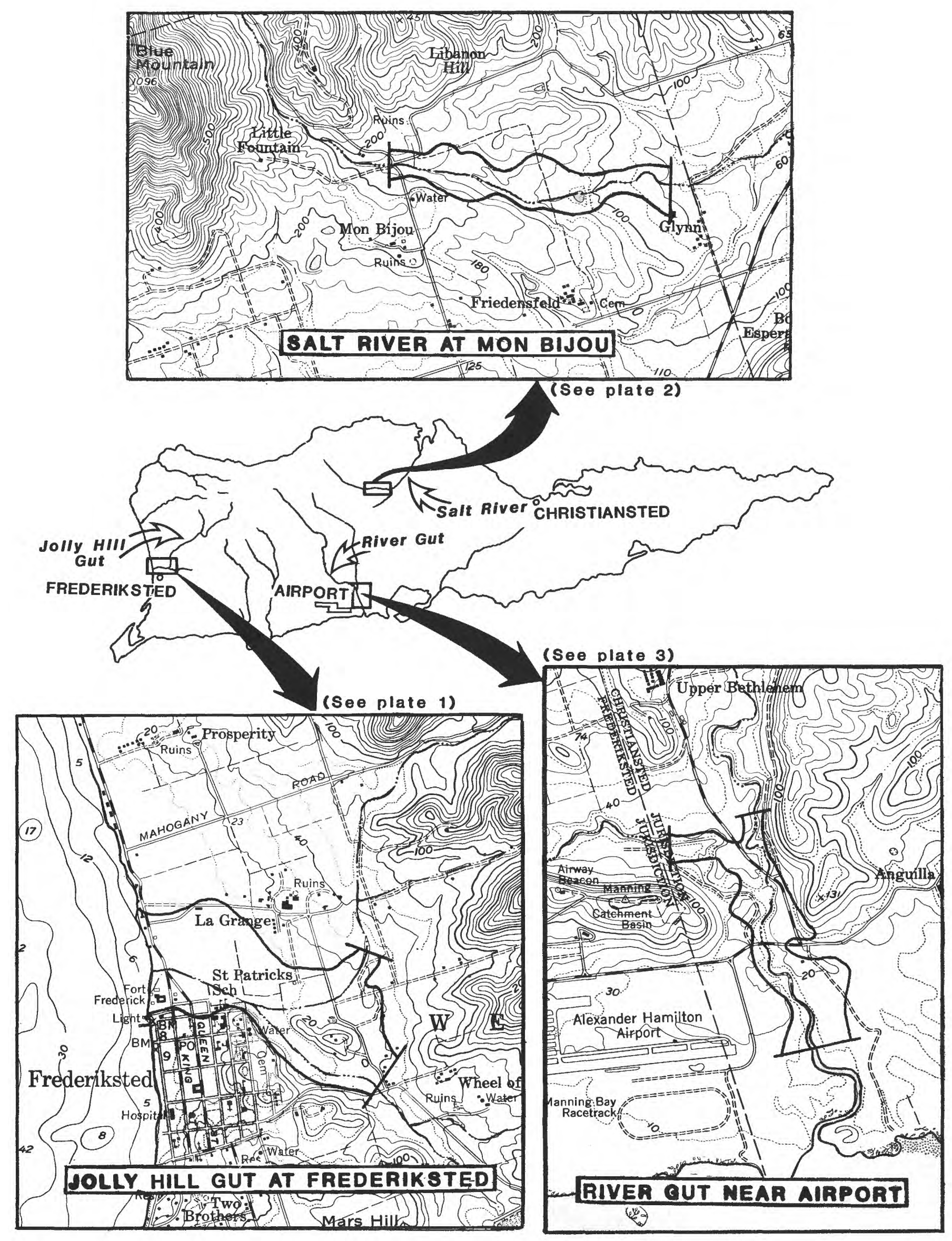

Figure 3.2-1. Flooded areas during the October 8, 1977 storm.

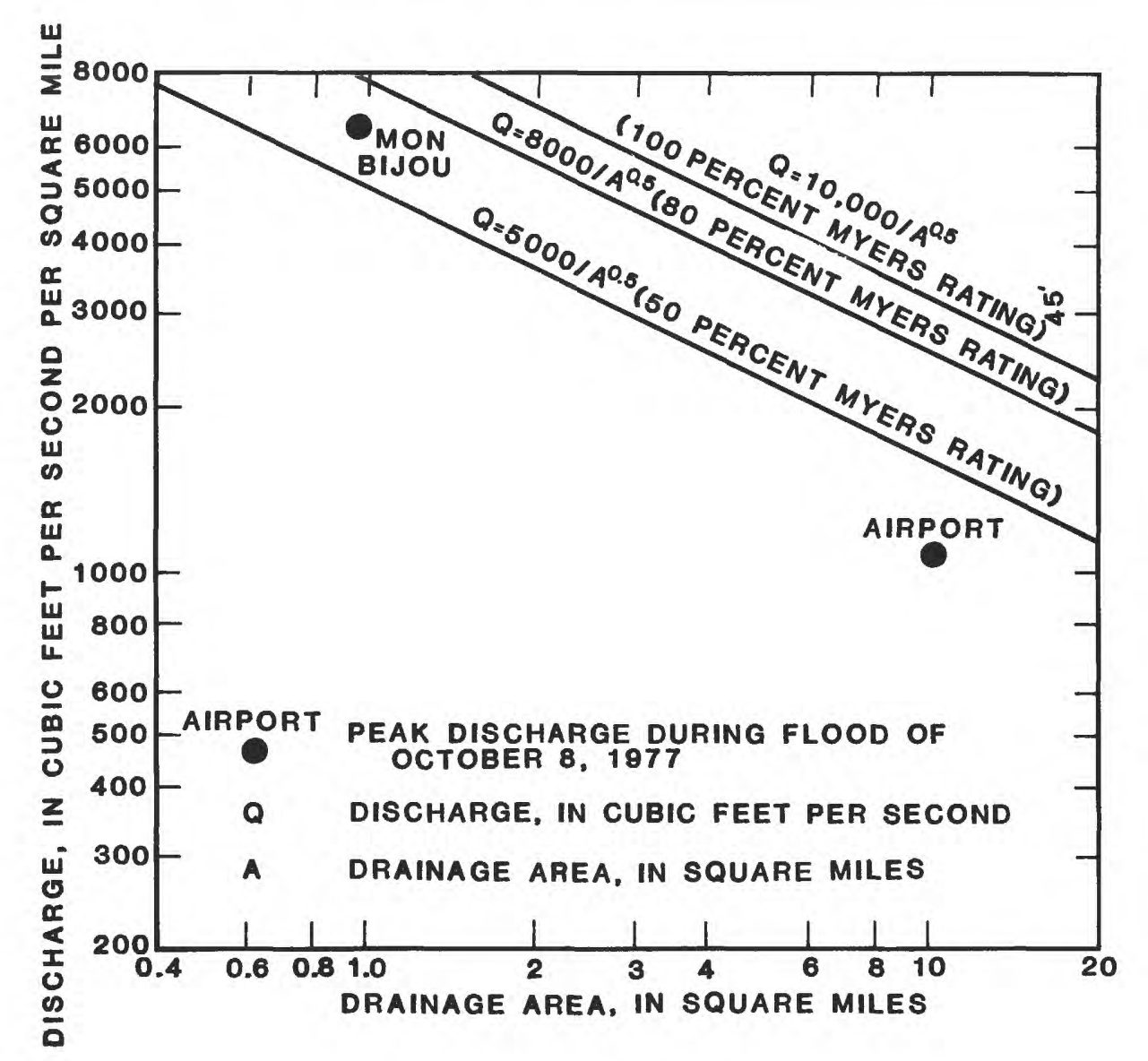

Figure 3.2-2. Peak discharges at Mon Bijou and near airport compared to Myer's historical floods.

3.0 THE FLOOD OF OCTOBER 8, 1977 (Continued) 3.2 PEAK DISCHARGE 
3.0 FLOOD OF OCTOBER 8, 1977 (Continued)

3.3 FLOOD PROFILES

\section{FLOOD PROFILES DEFINED AT THREE SITES}

Flood profiles were defined at

Jolly Hill Gut near Frederiksted, Salt River

at Mon Bijou, and River Gut near the airport.

A flood profile is a schematic drawing of a floodwave. The profile shows the water-surface elevation referenced to a datum (norma11y mean sea level) and distances along a base line following the general flow direction. The profiles can be defined from actual floodmark elevations or analyses, using computer techniques (Chow, 1959). Normally the profiles include the elevation of bridges, culverts, and other constraining structures along the channel.

Flood profiles were determined near Frederiksted (Jolly Hill Gut), Mon Bijou (Salt River), and near the Airport (River Gut). (Figure 3.3-1, and plates 1, 2, and 3 in pocket). The profiles are referenced to an arbitrary base line shown on plates 1-3. The base line and the profiles are not confined to the channel configuration, but follow a smoother path along the flood plain in the general direction of the floodflow. The profiles are based on actual floodmarks surveyed by personnel of the U.S. Geological Survey, Water Resources Division, shortly after the flood. 


\subsection{THE FLOOD OF OCTOBER 8, 1977 (Continued) \\ 3.4 DEPTH OF FLOODING IN URBAN AREAS}

\section{DEPTH OF WATER EXCEEDED 4 FEET}

\section{The Mon Bijou housing area was the most seriously affected, with water depths of as much as 4.5 feet.}

The depth of the the water in some of the flooded urban areas exceeded four feet. The housing project in Mon Bijou (plate 2), was the most affected area. The water depth in some of the houses was about 4.5 feet (fig. 3.4-1 and 3.4-2). Water depths of about 4 feet were also recorded in some areas near the Airport (fig. 3.4-3 and 3.4-4). In Frederiksted (plate 1), water depths did not exceed 2.5 feet (fig. 3.4-5 and 3.4-6). Most of the flooding occurred west and north of town.

Flooding as a result of the October 7-8, 1977 tropical disturbance was widespread throughout St. Croix. Although estimates of damages to public and private properties are not available, severe losses were reported by citizens and government officials. Flooding and damages were more intense in the populated areas near Mon Bijou and Frederiksted. 

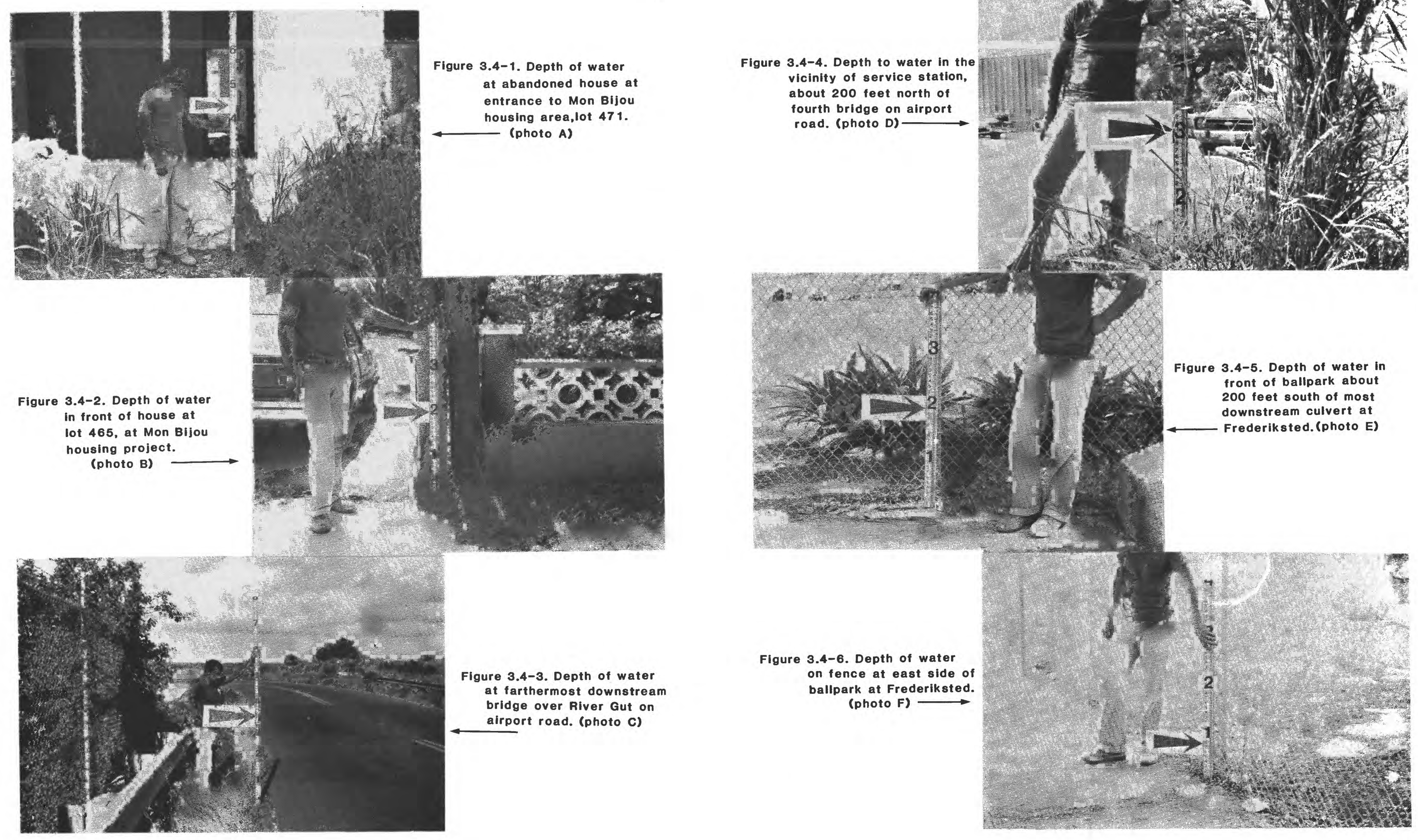

3.0 THE FLOOD OF OCTOBER 8,1977 (Continued) 3.4 DEPTH OF FLOODING IN URBAN AREAS 


\subsection{THE FLOOD OF OCTOBER 8, 1977 (Continued)}

\subsection{AREAS INUNDATED}

\section{THREE FLOOD MAPS DELINEATED}

\section{Maps delineate the inundated areas and show water surface contours at Federiksted, Mon Bijou, and the airport.}

The areas inundated by the October 8, 1977 flood are delineated on variable contour-interval topographic maps (fig. 3.5-1 and plates 1-3). The base maps for the Frederiksted and Airport areas (plates 1 and 3), were provided by the U.S. Virgin Islands Department of Public Works. The Mon Bijou area Map was delineated from a field survey by U.S. Geologica1 Survey employees.

Flood boundaries were delineated from high-water marks and field inspections of the affected areas shortily after the flood. The limits of the flood boundaries are approximate and may not reflect areas where shallow flooding occurred.

Water-surface contours on the flood maps (plates 1-3) are based on the elevations of the floodmarks and the flood profiles. The contours represent lines of equal elevation of the water surface at about a normal angle to the direction of flow. Obstructions to the flow, such as man-made structure and vegetation, can cause irregularities in the contours. In the Mon Bijou area, the flow of the floodwaters was obstructed by the buildings in a housing project. A similar condition was observed in the Frederiksted area, where fences and buildings also obstructed some of the flow. The approximate depth of flooding at any point in the inundated areas can be estimated by substracting the ground elevation from the water-surface contour. Interpolation can be used to estimate points between contours. 


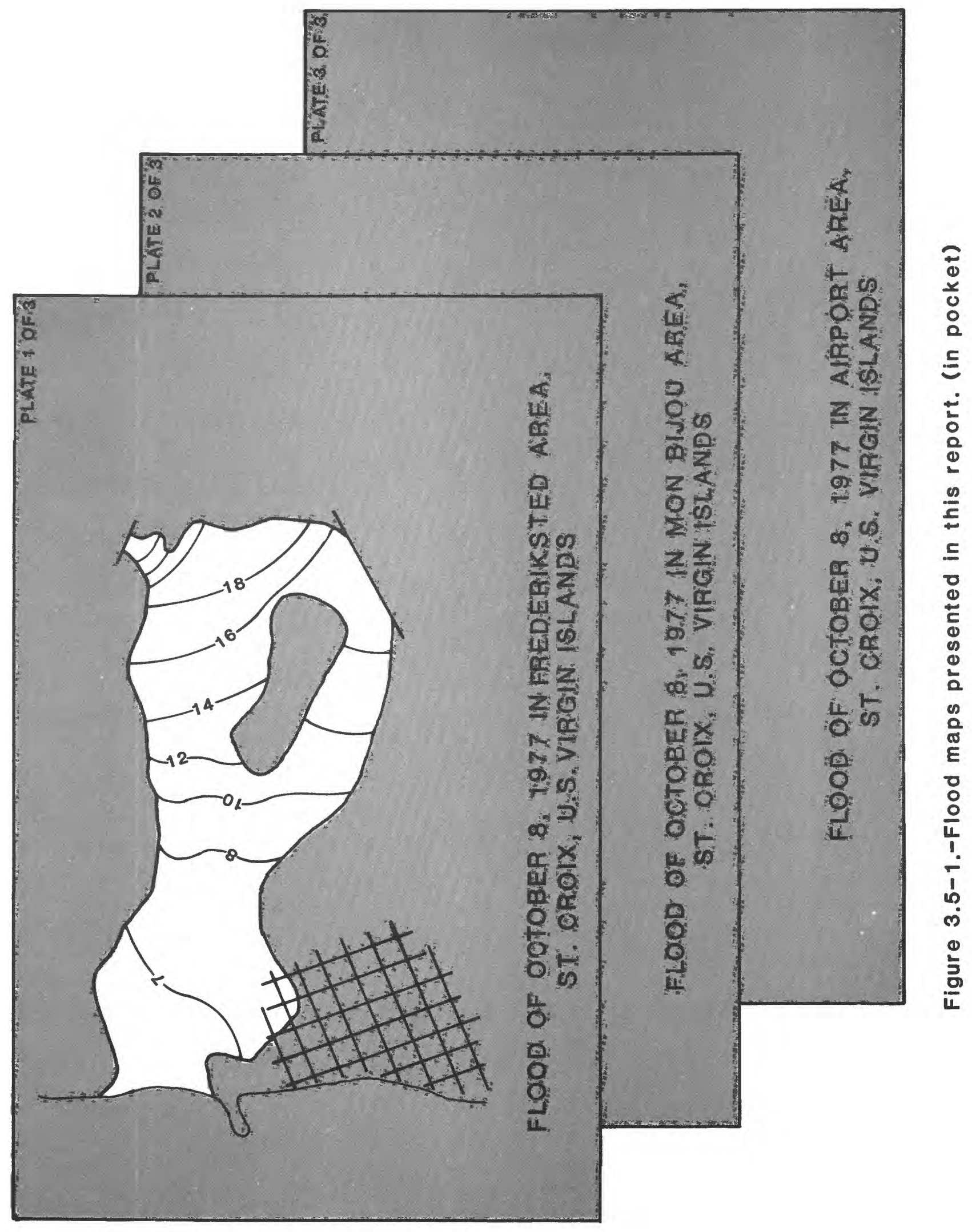

3.0 THE FLOOD OF OCTOBER 8, 1977 (Continued) 3.5 AREAS INUNDATED 


\subsection{ELEVATION OF BRIDGES AND CULVERTS AND REFERENCE MARKS}

\section{ELEVATION OF 14 BRIDGES OR CULVERTS AND FOUR REFERENCE MARKS ESTABLISHED}

\section{Elevations of 3 structures in the Frederiksted area, 6 in the Mon Bijou area, and 5 in the airport area were established.}

The elevations of bridges and culverts in the flooded area are important hydrologic data. The depth of the floodwaters relative to bridge structures can be obtained from flood profiles (see section 3.3 ). These elevations can be used for future flood studies, design and alteration of structures. Flood stages and back-water conditions may be affected by such structures.

Elevations of bridges in the Frederiksted, Mon Bijou, and the Airport areas are shown in tables 4.0-1 to 4.0-3. The locations of the bridges are referenced to the base line on plates 1-3 and shown by means of a map symbol.

Reference marks are usually established to define the depth of water along a flooded area. The marks can also be utilized for future studies and comparisons between different floods. The elevation of the marks is referenced to a mean sea-level datum (MSI.). The permanent marks established during this study are listed in table 4.0-4. 
Table 4.0-1 Elevation of bridges in the Frederiksted area. (plate 1)

\begin{tabular}{c|c|c|c}
\hline \multirow{2}{*}{$\begin{array}{c}\text { Map } \\
\text { Symbo1 }\end{array}$} & $\begin{array}{c}\text { Stationing } \\
\text { along base } \\
\text { line, in feet }\end{array}$ & \multicolumn{2}{|c}{$\begin{array}{c}\text { Bridge elevation } \\
\text { in feet (mean sea leve1 } \\
\text { datum) }\end{array}$} \\
\cline { 3 - 4 } & & $\begin{array}{c}\text { Top of } \\
\text { Deck }\end{array}$ & \multicolumn{2}{|c}{$\begin{array}{c}\text { Low } \\
\text { Beam }\end{array}$} \\
\hline A & & 5.5 & 3.0 \\
B & 350 & 5.4 & 4.3 \\
C & 93.0 & 14.2 & 12.7 \\
\hline
\end{tabular}

Table 4.0-2 Elevation of bridges in the Mon Bijou area. (plate 2)

\begin{tabular}{|c|c|c|c|c|}
\hline \multirow[t]{2}{*}{$\begin{array}{c}\text { Map } \\
\text { Symbo1 }\end{array}$} & \multirow[t]{2}{*}{$\begin{array}{l}\text { Stationing } \\
\text { along base } \\
\text { line, in feet }\end{array}$} & \multicolumn{3}{|c|}{$\begin{array}{l}\text { Bridge elevation } \\
\text { in feet (mean sea level } \\
\text { datum) }\end{array}$} \\
\hline & & $\begin{array}{l}\text { Top of } \\
\text { Deck }\end{array}$ & $\begin{array}{l}\text { Low } \\
\text { Beam }\end{array}$ & \\
\hline $\mathbf{A}$ & 260 & 86.1 & 83.4 & \\
\hline B & 1580 & 114.7 & 110.5 & \\
\hline C & 3350 & 150.1 & 149.5 & \\
\hline D & .3530 & 152.1 & 151.5 & $\begin{array}{l}\text { Underground } \\
\text { channel outlet }\end{array}$ \\
\hline $\mathbf{E}$ & 4035 & 163.7 & 162.9 & $\begin{array}{l}\text { Underground } \\
\text { channel inlet }\end{array}$ \\
\hline F & 4240 & 171.0 & 170.2 & \\
\hline
\end{tabular}

Table 4.0-3 Elevation of bridges in the airport area. (plate 3)

\begin{tabular}{|c|c|c|c|c|}
\hline \multirow[t]{2}{*}{$\begin{array}{c}\text { Map } \\
\text { Symbol }\end{array}$} & \multirow[t]{2}{*}{$\begin{array}{l}\text { Stationing } \\
\text { along base } \\
\text { line, in feet }\end{array}$} & \multicolumn{3}{|c|}{$\begin{array}{l}\text { Bidge elevation } \\
\text { in feet (mean sea level } \\
\text { datum) }\end{array}$} \\
\hline & & $\begin{array}{c}\text { Top of } \\
\text { Deck. }\end{array}$ & $\begin{array}{l}\text { Low } \\
\text { Beam }\end{array}$ & \\
\hline $\begin{array}{l}\text { A } \\
\text { B } \\
\text { C } \\
C^{\prime} \\
\text { D }\end{array}$ & $\begin{array}{l}2970 \\
4230 \\
5180 \\
5180 \\
5400\end{array}$ & $\begin{array}{r}16.7 \\
8.0 \\
21.7 \\
20.3 \\
26.0\end{array}$ & $\begin{array}{r}12.1 \\
7.0 \\
18.5 \\
17.1 \\
23.9\end{array}$ & $\begin{array}{l}\text { I,eft opening } \\
\text { Right opening }\end{array}$ \\
\hline
\end{tabular}

Table 4.0-4 Reference marks established by the U.S. Geological Survey Water Resources Division in St. Croix, U.S. Virgin Islands after the October 8, 1977 flood. (plates 1-3)

\begin{tabular}{|c|c|c|c|}
\hline Map & Symbo1 & Description & $\begin{array}{c}\text { EJevation in feet } \\
\text { above mean sea level }\end{array}$ \\
\hline $\mathrm{RM}$ & 1 & $\begin{array}{l}\text { Chise11ed square, painted red, on downstream side of culvert } \\
\text { headwall at entrance road to Mon Bijou; the most upstream } \\
\text { culvert. }\end{array}$ & 172.23 \\
\hline $\mathrm{RM}$ & 2 & $\begin{array}{l}\text { Chiselled square, painted red, on left upstream side of bridge } \\
\text { at handrail foundation, over River Gut at the most downstream } \\
\text { bridge of the Alrport road. }\end{array}$ & 17.81 \\
\hline $\mathrm{RM}$ & 3 & $\begin{array}{l}\text { Chiselled square, painted red, on upstream side of bridge } \\
\text { abutment of left bridge, over River Gut at New Center Line } \\
\text { highway. }\end{array}$ & 18.46 \\
\hline $\mathrm{RM}$ & 4 & $\begin{array}{l}\text { Chiselled square, painted red, on right upstream side of } \\
\text { culvert headwall on second culvert in upstream order, over } \\
\text { Jolly H111 Gut on north side of Frederiksted. }\end{array}$ & 6.45 \\
\hline
\end{tabular}




\subsection{LIST OF REFERENCES}

Barnes, H.H., Jr., and Bogart, D.B., 1961, Floods of September 6, 1960 in eastern Puerto Rico: U.S. Geological Survey Circular, 451, 13 p.

Haire, W.J., and Johnson, K.G., 1978, Floods of November 11-13, 1974 in St. Croix, U.S. Virgin Islands: U.S. Geological Survey WaterResources Investigations $77-136,7$ plates.

Lindsey, R.K., Kohler, M.A., and Daulhus, J., 1949, Applied Hydrology: New York, McGraw Hill Inc., 689 p.

Jordan, D.G., 1975, A survey of the water resources of St. Croix, U.S. Virgin Islands: U.S. Geological Survey Open-File Report, $51 \mathrm{p}$.

Robison, T.M., 1.975, Ground water in central St. Croix, U.S. Virgin Islands: U.S. Geological Survey Open-File Report, 18 p.

U.S. Geological Survey, 1976, Flood-prone area maps of St. Croix, U.S. Virgin Islands: unpublished maps (3) available for inspection at the U.S. Geological Survey office, WRD, Ft. Buchanan, Puerto Rico. 
PRECIPITATION STATIONS AND CUMULATIVE PRECIPITATION DURING THE OCTOBER 7-8, 1977 AND SEPTEMBER 4, 1979 STORMS

\begin{tabular}{|c|c|c|c|}
\hline \multirow{2}{*}{$\begin{array}{c}\text { MAP } \\
\text { NUMBER }\end{array}$} & \multirow{2}{*}{ STATION LOCATION } & \multicolumn{2}{|c|}{ CUMULATIVE PRECIPITATION } \\
\hline & & ОСТОВЕR 7-8, 1977 & SEPTEMBER 4,1879 \\
\hline 1 & Alexander Hamilton Airport & 10.04 & 17.15 \\
\hline 2 & Annaly & 16.00 & 16.00 \\
\hline 3 & Annas Hope & 14.25 & 20.00 \\
\hline 4 & Beth Upper New Works & 13.20 & 15.50 \\
\hline 5 & Castle Nugent & 12.60 & - \\
\hline 6 & Christiansted Fort & 14.09 & 16.36 \\
\hline 7 & East Hill & 10.94 & 15.32 \\
\hline 8 & Estate Rust-Up Twist & 14.75 & 17.97 \\
\hline 9 & Fountain & 13.00 & 12.00 \\
\hline 10 & Frederiksted & - & 11.40 \\
\hline 11 & Gianard & 12.04 & 15.56 \\
\hline 12 & Ham Bluff LH Station & 12.38 & - \\
\hline 13 & Kings Hill & 8.00 & - \\
\hline 14 & Tague Bay & 11.20 & 18.00 \\
\hline
\end{tabular}


